\title{
Comparative Study Between China 2018 National Accreditation Standard for Teaching Quality of Clinical Pharmacy and ACPE 2015 Accreditation Standards and Guidelines
}

\author{
Zeinab Abdelrahman, Qi-Yue Zhang, Chang-Qing Yang* \\ School of Basic Medicine and Clinical Pharmacy, China Pharmaceutical University, Nanjing, CHINA.
}

\begin{abstract}
Background: Rapid development of the China economy has gradually increase the demand of the medical resources. To please this increasing demand for enhanced medical services, National Health Commission of the People's Republic of China has set an "Interim Provisions Administration of Pharmaceutical Affairs in Medical Institutions" in 2002 stated that "the clinical pharmacist should take part in the diagnosis and treatment of disease, provide pharmaceutical care and improve the quality of medical care". According to these recommendations many colleges and universities have established training programs that are corresponding to the Doctor of Pharmacy (Pharm.D) curriculum in the United States but these universities/ colleges until 2018 have not implemented any uniform curriculum standards for program duration and degree titles. So, in March 2018, China Teaching committee for pharmacy specialty has made a considerable progression decision to improve clinical pharmacy education by providing the first national accreditation standards offered by the Ministry of Education of the People's Republic of China (MOE). Materials and Methods: This paper has used descriptive and comparative method to evaluate and compare national accreditation standard for teaching quality of pharmacy in China. According to the ACPE 2015 accreditation standards and guidelines (25 elements). Conclusion: some recommendations and suggestion are stated to enhance and develop this Accreditation to the level of Pharm.D program such as foundational knowledge core, summarized annual assessments of student achievement of relevant didactic and dean responsibilities and other administrative leadership team members tasks need to be clearly stated.
\end{abstract}

Key words: Clinical pharmacy, MOE, ACPE, Standards and guidelines, China 2018 national accreditation and standards.

\section{INTRODUCTION}

Rapid development of the China economy has gradually increase the demand of the medical resources, which driving people to set higher prospects for the quality of medical services in China. To please this increasing demand for enhanced medical services, National Health Commission of the People's Republic of China (in past called: China's Ministry of Public Health) has set an "Interim Provisions Administration of Pharmaceutical Affairs in Medical Institutions" in 2002 stated that "the clinical pharmacist should take part in the diagnosis and treatment of disease, provide pharmaceutical care and improve the quality of medical care". According to these recommendations many colleges and universities have established training programs that are corresponding to the doctor of pharmacy (Pharm D) curriculum in the United States. Since 2006, the number of colleges and universities offered clinical pharmacy education programs in China, were 45 colleges. The duration of the programs varied
Submission Date: 09-03-2019; Revision Date: 17-05-2019; Accepted Date: 04-09-2019

DOI: 10.5530/ijper.53.4.124 Correspondence: Chang-Qing Yang (PhD), Professor of Clinical Pharmacy, School of Basic Medicine and Clinical Pharmacy, China Pharmaceutical University, Nanjing-211198, CHINA.

Phone: +8615005179447

Email: ycq0315@yahoo.com

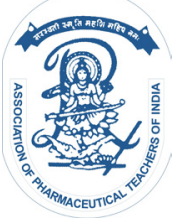

www.ijper.org 
between 4 to 7 years, for which students are awarded different degrees according to the length and the type of program, these programs are: Bachelor of Medicine, Bachelor of Science, Master of Science and Master of Medicine. These universities and colleges until 2014 have not implemented any uniform curriculum standards for program duration and degree titles. From 2015, all universities or colleges set the same duration of the program which is 5 years. The major curriculum contents in each school offered clinical pharmacy program contain set of mix courses of humanities and social sciences (including physics, mathematics, Pharmacoeconomics, ethics, professional communication skills and statistics), biomedical sciences (including anatomy, pathology, microbiology and immunology), pharmaceutical sciences including (medicinal chemistry, pharmacology, bioanalysis chemistry, pharmaceutics, pharmacokinetics and biopharmaceutics), clinical science (including pharmacotherapy and internal medicine) and Pharmacy Practice Experiences (PPEs) with a duration of six month to one year according to the length of the training program offered from each school or college. ${ }^{1,2}$ Till 2018, there was lacking of united accreditation standards and guidelines, according to this fact colleges and universities in China have not yet achieved consistency of training goals, curriculum, program duration and degree titles. Thereby, development of pharmacy education necessitates the establishment of the national accreditation agency that can formulate standards and guidelines for teaching clinical pharmacy. So, in March 2018, China Teaching committee has made a considerable progression decision to improve clinical pharmacy education by providing the first national accreditation standard for teaching quality of pharmacy in China offered by the Ministry of Education of the People's Republic of China (MOE). ${ }^{3}$ The mission of these accreditation standards is to evaluate and ensure continues quality improvement of education. They also address some structural and process related elements within pharmacy education necessary to implement evidence based outcome measures that document accomplishment of these standards. In addition, these standards describe areas where programs can innovate within the didactic component of the curriculum to meet the required educational outcomes. Consequently, adopting of clinical pharmacy professionals for medical institutions will become one of the important tasks of the medical colleges/ universities in China.

Our mission in this paper is to give a detailed evaluation and comparison of China national accreditation standards 2018 and this comparison will be provided according to the ACPE 2015 accreditation standards and guidelines, some recommendations and suggestion are given about how to enhance and develop the China national accreditation to the level of Pharm.D program.

\section{MATERIALS AND METHODS}

A descriptive and comparative method is used and a discussion was carried out between authors. Current China national accreditation standards 2018 is evaluated and compared with ACPE 2015 accreditation standards and guidelines according to the ACPE three major sections: 1) Educational Outcomes (contain 4 standard elements), 2) Structure and Process to Promote Achievement of Educational Outcomes (contain 23 standard elements), 3) Assessment of standards and key elements (contain 2 elements). In addition, we have searched PubMed, Google Scholar and Baidu scholar for articles discussed the clinical pharmacy situation in China, to be able to understand the vision and goals of this program and to verify if this program is able to satisfy the graduates' desire to be a successful clinical pharmacist and to be 'practice-ready' and 'team-ready'.

\section{RESULTS AND DISCUSSION}

In USA Pharm.D curriculum is developed according to ACPE standards and guidelines. Every school follow the same guidelines with enough authorization for innovation. While in China different schools developed their own curriculum for clinical pharmacy bachelor's degree program.

As mentioned above, China ministry of education has created the first accreditation standard of clinical pharmacy bachelor's degree in March 2018, which states that bachelor's degree will be five years. On the other hand, the Doctor of Pharmacy (Pharm.D) program of ACPE 2015 accreditation standards and guidelines requires at least 2-years of specific preprofessional (undergraduate) coursework followed by 4-academic years (or 3-calendar years) of professional study. We are going to mention in details the major differences between the two accreditation standards according to the $25 \mathrm{ACPE}$ standard elements.

These standard elements focused on the educational outcomes and the assessment of those outcomes by addressing the structural and process-related elements within pharmacy education necessary to implement evidence-based outcome measures that document achievement of these standards, describe areas where programs can experiment and revolutionize within the moral and experiential components of their curricular to meet the required educational outcomes and last 
but not least to establish a commitment to continuing professional development (CPD) by the students and graduates to ensure that they will be 'practice-ready' and 'team-ready'.

\section{Section One: Educational Outcome}

This section focused on the essential current practice of pharmacy in the healthcare setting that demands interprofessional teamwork and professional responsibility for full patient well-being. According to the ACPE 2015 accreditation standards and guidelines, this section has four standard elements that China national accreditation standards will be compared to. Detailed comparison according to the educational outcomes between the two programs shown in Table 1. Although there were merging in the skills and knowledge requirements in China 2018 accreditation standards, these standards has upgraded to the ACPE 2015 first section standards elements successfully and deemed the essential to the contemporary practice of pharmacy in the healthcare facilities.

\section{Section Two: Structure and Process to Encourage Success of Educational Outcomes}

In this section, the ACPE 2015 accreditation standards described the essential structures that provide the organizational stability and the potential for development to continuous quality improvement in pharmacy education. The ACPE 2015 accreditation standards reflects this section in total of 19 standards under four different subsections: 1) planning and organization, 2) educational program for the Doctor of Pharmacy degree, 3) students and 4) resources. Meanwhile, China 2018 accreditation standards was mention some of these standards' dispersal between different sections. Half of these standards were briefly mention while other half were mention in detail's as shown in Tables 2-5.

\section{Subsection One: Planning and Organization}

One of the most important questions is, "does the quantity of the teaching staff is more important than the qualification of this staff or there must be an "equality importance" in both sides?" Another question

\section{Table 1: Comparison of Educational Outcomes Standards Elements Between the ACPE 2015 and China 2018.}

\begin{tabular}{|c|c|c|}
\hline Elements & ACPE standards 2015 & China standards 2018 \\
\hline $\begin{array}{l}\text { 1. Foundational } \\
\text { Knowledge }\end{array}$ & $\begin{array}{l}\text { Concerns about developing and } \\
\text { applying knowledge from the } \\
\text { foundational sciences to make the } \\
\text { graduate be able to evaluate the } \\
\text { scientific literature, explain drug action, } \\
\text { solve therapeutic problems and advance } \\
\text { population health and patient-centered } \\
\text { care. }\end{array}$ & $\begin{array}{l}\text { focus on how to develop and apply knowledge from } \\
\text { foundational sciences (chemistry, biology, humanities, } \\
\text { social sciences, pharmaceutical chemistry and } \\
\text { pharmacology). } \\
\text { The graduate will be familiar with the basic mechanism } \\
\text { of diseases, diagnostic criteria, how to make } \\
\text { successful treatment plans, be capable to understand } \\
\text { the pharmacokinetics-pharmacodynamics and the } \\
\text { mechanisms of action of drugs under normal conditions } \\
\text { and disease conditions. } \\
\text { The graduate also will be able to gain knowledge, skills, } \\
\text { abilities, behaviors and attitudes of how to evaluate } \\
\text { clinical drug safety and gaining of strong foundational } \\
\text { knowledge of clinical pharmacotherapy, clinical } \\
\text { Pharmacoeconomics and relevant regulations and } \\
\text { policies for pharmacy management. }\end{array}$ \\
\hline $\begin{array}{l}\text { 2. Essentials For } \\
\text { Practice And Care }\end{array}$ & $\begin{array}{l}\text { The capability to provide patient- } \\
\text { centered care as the medication expert } \\
\text { and managing patient healthcare. }\end{array}$ & $\begin{array}{l}\text { It imparts to the graduates the knowledge, skills and } \\
\text { abilities necessary of how to collect patient information } \\
\text { probably, writing the medication history, review and } \\
\text { dispenses prescriptions, how to use the information data } \\
\text { base to collect and to evaluate the drug information and } \\
\text { providing drug information services probably. }\end{array}$ \\
\hline $\begin{array}{l}\text { 3. Approach to } \\
\text { Practice and Care }\end{array}$ & $\begin{array}{l}\text { Gaining the knowledge, skills, } \\
\text { behaviors, and attitudes necessary to } \\
\text { solve problems and having the ability to } \\
\text { educate, advocate, collaborate and work } \\
\text { with a broad range of people. }\end{array}$ & $\begin{array}{l}\text { The ability to provide clinical pharmacy services such as } \\
\text { drug consultation, monitoring of adverse drug reactions, } \\
\text { designing individualized drug regimens needed for } \\
\text { rational drug use. }\end{array}$ \\
\hline $\begin{array}{l}\text { 4. Personal and } \\
\text { Professional } \\
\text { Development }\end{array}$ & $\begin{array}{l}\text { Gaining the sufficient knowledge } \\
\text { necessary to demonstrate self- } \\
\text { awareness, and professionalism }{ }^{4,5} \text {. }\end{array}$ & $\begin{array}{l}\text { - Gaining skills and be able to effectively communicate } \\
\text { verbally and nonverbally with patients and their families, } \\
\text { as well as the medical staff. }{ }^{2}\end{array}$ \\
\hline
\end{tabular}


Table 2: Comparison of Curriculum Planning and Organization Goals Between ACPE 2015 and China 2018.

\begin{tabular}{|c|c|c|}
\hline Elements & ACPE standard 2015 & China standard 2018 \\
\hline $\begin{array}{l}\text { 5. Eligibility and Reporting } \\
\text { Requirements }\end{array}$ & $\begin{array}{l}\text { - It focuses on PharmD as an independent } \\
\text { entity. Legal empowerment to award Pharm } \\
\text { D. Dean leads the college or school who is } \\
\text { responsible for ensuring that all accreditation } \\
\text { requirements of ACPE is met. Regional/ } \\
\text { institutional accreditation and actions } \\
\text { (summarized in reporting any issues that } \\
\text { negatively impact the program to the ACPE } \\
\text { within } 30 \text { days) report any substantive } \\
\text { changes to the ACPE for further evaluation. }\end{array}$ & $\begin{array}{l}\text { - } \quad \text { not mention that the clinical pharmacy } \\
\text { program will be an independent entity. } \\
\text { did not state what is the dean's (that will lead } \\
\text { this program) qualification, requirements and } \\
\text { the responsibilities to ensure and evaluate } \\
\text { the accreditation curriculum is consistent and } \\
\text { implemented properly. } \\
\text { The person in charge of the professional core } \\
\text { curriculum must have senior professional and } \\
\text { technical positions and the professional core } \\
\text { curriculum instructors should have a certain } \\
\text { amount of time each year to participate } \\
\text { in professional practice activities such as } \\
\text { teaching in teaching practice base. }\end{array}$ \\
\hline $\begin{array}{l}\text { 6. College Or School } \\
\text { Vision, Mission and } \\
\text { Goals }\end{array}$ & $\begin{array}{l}\text { summarized in commitment to educational } \\
\text { outcomes, education, scholarships, services } \\
\text { and practice, consistency of initiatives and } \\
\text { subunit goals and objectives arrangement. }\end{array}$ & $\begin{array}{l}\text { - the clinical pharmacy bachelor program will } \\
\text { be taught as a professional degree without } \\
\text { discuss any further information about is it } \\
\text { going to be independent school/college entity } \\
\text { or will be dependent entity under other school/ } \\
\text { college professional degrees. } \\
\text { the students will graduate with Bachelor of } \\
\text { Science degree with curriculum of clinical } \\
\text { pharmacy degree. }\end{array}$ \\
\hline 7. Strategic Plan & $\begin{array}{l}\text { The college or school members develops and } \\
\text { revises on a continuing foundation of strategic } \\
\text { plan that includes strategies to advance its } \\
\text { vision and goals. }\end{array}$ & - Not mention \\
\hline $\begin{array}{l}\text { 8. Organization and } \\
\text { Governance }\end{array}$ & $\begin{array}{l}\text { The college or school is organized and } \\
\text { staffed to facilitate the accomplishment of } \\
\text { its missions by several elements such as } \\
\text { leadership collaboration, qualified dean with } \\
\text { administrative responsibilities and qualified } \\
\text { administrative team. }\end{array}$ & $\begin{array}{l}\text { - The faculty instructor's quantity and } \\
\text { qualification are cored only on the necessity } \\
\text { of teaching staff requirement to be master } \\
\text { or doctoral degree holders without mention } \\
\text { clinical pharmacy as specialty or any related } \\
\text { specialized field. } \\
\text { The number of full-time lecturers to meet the } \\
\text { teaching needs of the professional and the } \\
\text { ratio of students to teachers is not higher } \\
\text { than } 18: 1 \text {. The number of full-time clinical } \\
\text { pharmacists in health facilities who meet } \\
\text { the teaching qualification should be no less } \\
\text { than } 5 \text { and shall hold a certificate of training } \\
\text { for clinical pharmacists issued by relevant } \\
\text { authorities }{ }^{2} \text {. }\end{array}$ \\
\hline 9. Organizational Culture & $\begin{array}{l}\text { to ensure self-directed lifetime learning, } \\
\text { professional behavior, leadership and } \\
\text { teamwork within academic units and } \\
\text { professions } s^{4,5} \text {. }\end{array}$ & - Not mention \\
\hline
\end{tabular}

is that what is the exact "senior professional and technical positions" "qualification of the dean that responsible for implement and developed the curriculum?" These questions need further detailed explanation to ensure the consistency and the development of the new program. According to ACPE 2015 accreditation standards and guidelines, both the quality and the quantity of the teaching staff have fair equal status, but on the other hand, China 2018 accreditation standards focused on the quantity of the teaching staff more than the quality of them, which could affect the academic achievement and the foundational gained knowledge of the students and graduates.

As clinical pharmacist point of view, both sides shall have fair equal importance. Gaining knowledge and acquiring skills will not be accomplished by crowded classrooms with more than 200 students or by unqualified tutors that their academic background totally different from the clinical pharmacy professional instead of individuals with academic credentials and expertise that are explicitly linked to their teaching responsibilities. The academic background should be in the same 


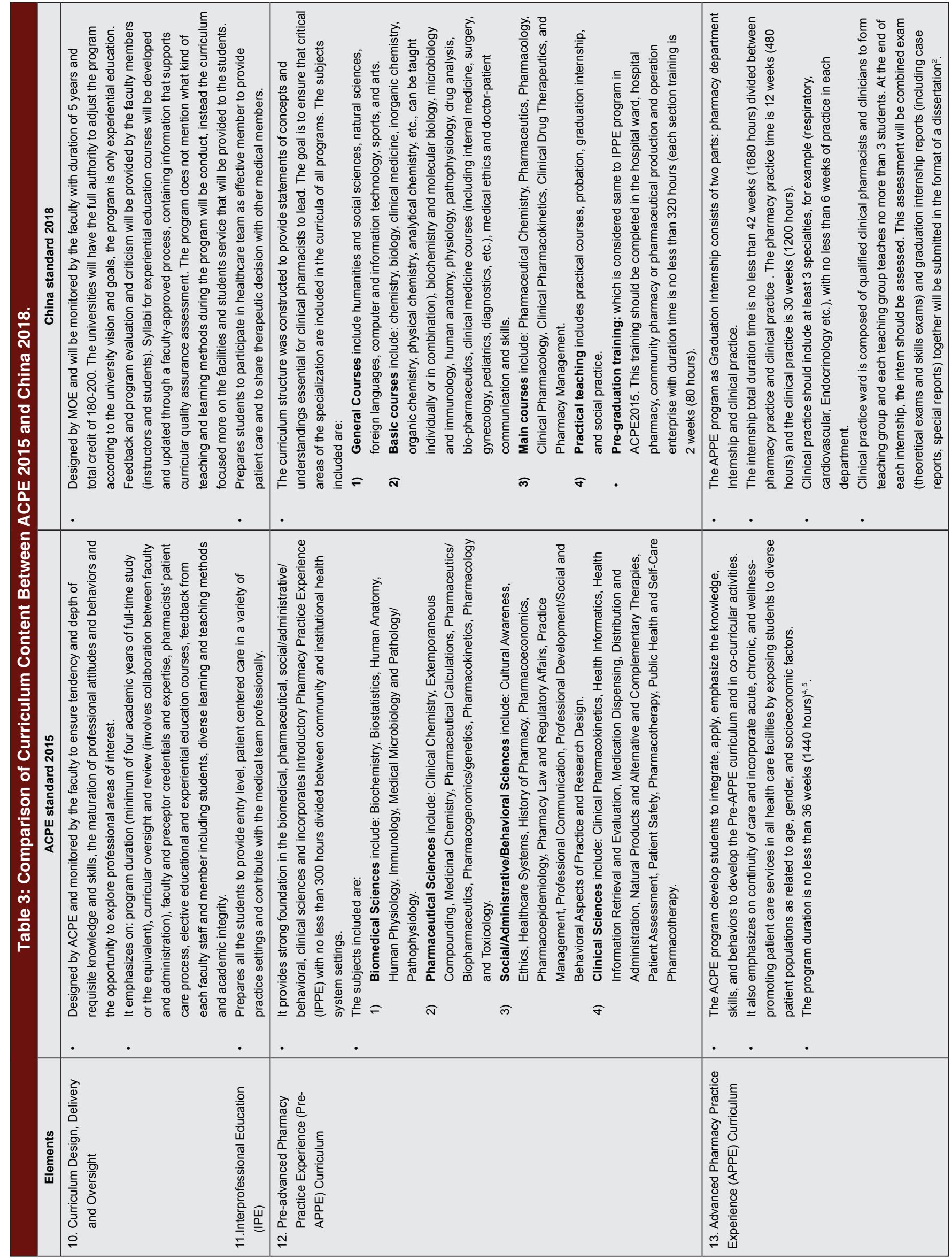




\section{Table 4: Students' Services Differences Between ACPE 2015 and China 2018 Programs}

\begin{tabular}{|c|c|c|}
\hline Elements & ACPE standard 2015 & China standard 2018 \\
\hline $\begin{array}{l}\text { 14,15,16. Students Services, } \\
\text { Academic Environment and } \\
\text { Admissions }\end{array}$ & $\begin{array}{l}\text { - The ACPE curriculum provide different } \\
\text { services to students to endorse student } \\
\text { success and wellbeing. } \\
\text { These services include: } \\
\text { 1) FERPA (family educational rights and } \\
\text { privacy act) which is secure system for } \\
\text { recording student's records } \\
\text { 2) financial aid; } \\
\text { 3) healthcare; } \\
\text { 4) advising; } \\
\text { 5) non-discrimination; } \\
\text { 6) disability accommodation; } \\
\text { 7) student services access complaints; } \\
\text { 8) distance learning policies. } \\
\text { Each college or school develops and } \\
\text { implements its admission criteria, policies } \\
\text { and procedures to ensure the selection of } \\
\text { a qualified and diverse students into the } \\
\text { professional degree program. }\end{array}$ & $\begin{array}{l}\text { Did not mention what kind of students } \\
\text { services each school or college must } \\
\text { provide to assess learning and teaching } \\
\text { development except for small part in } \\
\text { curriculum mention that "there should } \\
\text { be classrooms, laboratories, on-campus } \\
\text { and off-campus training bases, and other } \\
\text { teaching facilities that must meet the needs } \\
\text { of clinical pharmacy education in quantity } \\
\text { and function". } \\
\text { Did not mention admission criteria and } \\
\text { procedure of selection. }\end{array}$ \\
\hline 17. Progression & $\begin{array}{l}\text { Colleges or schools implement and } \\
\text { assesses the policies and procedures of } \\
\text { student's progression through the Pharm D } \\
\text { program such as (missed course work or } \\
\text { credit, leaves of absence, grade appeals. } \\
\text { etc) }{ }^{4,5} \text {. }\end{array}$ & $\begin{array}{l}\text { Did not mention how the schools or colleges } \\
\text { will implement progression policies like } \\
\text { (e.g., academic progression and probation, } \\
\text { remediation, and missed course work or } \\
\text { credit). }\end{array}$ \\
\hline
\end{tabular}

\section{Table 5: Comparison of the Staff, Preceptors, and other Resources Between ACPE 2015 and China 2018} Programs.

\begin{tabular}{|c|c|c|}
\hline Elements & ACPE standard 2015 & China standard 2018 \\
\hline $\begin{array}{l}\text { 18, 19: Faculty And Staff } \\
\text { Qualitative And Quantitative }\end{array}$ & $\begin{array}{l}\text { Emphasizes on qualification, experience, number, } \\
\text { academic credentials and expertise proportionate with } \\
\text { the staff responsibilities. }\end{array}$ & $\begin{array}{l}\text { Did not mention concisely what is the qualitative } \\
\text { requirements for the faculty and staff. }\end{array}$ \\
\hline $\begin{array}{l}\text { 20,21,22,23: Preceptors } \\
\text { Quality And Quantity, } \\
\text { Physical Facilities And } \\
\text { Educational Resources, } \\
\text { Practice Facilities And } \\
\text { Financial Resources }\end{array}$ & $\begin{array}{l}\text { Emphasizes on the preceptors qualification and } \\
\text { quantification, preceptor's education development, } \\
\text { physical facilities such as (classrooms and } \\
\text { laboratories), educational and practice facilities which } \\
\text { subject to annual evaluation to improve student } \\
\text { learning outcome, and financial resources to support } \\
\text { the firmness of the educational programme. } .^{5}\end{array}$ & $\begin{array}{l}\text { - Focuses on the faculty staff and preceptor's } \\
\text { quantity factor and briefly the quality factors of the } \\
\text { preceptors. } \\
\text { The quality factor of the preceptors is approximately } \\
\text { same to the preceptor's requirements stated in the } \\
\text { ACPE curriculum. } \\
\text { These requirements are: } \\
\text { 1) Bachelor's degree or above in pharmaceutical } \\
\text { science with technical professional titles } \\
\text { middle level or above. } \\
\text { 2) Clinical practices should be composed of } \\
\text { qualified teaching pharmacists and teaching } \\
\text { physicians and the number of students } \\
\text { in each group should not exceed 3. The } \\
\text { teaching pharmacist at the clinical practices } \\
\text { should hold a certificate for training clinical } \\
\text { pharmacists issued by an authoritative } \\
\text { organization. The teaching physicians should } \\
\text { be doctor with intermediate and above } \\
\text { specialized technical positions. } \\
\text { The preceptors should be familiar with the } \\
\text { system theory knowledge of the professional, } \\
\text { have rich working experience, strong teaching } \\
\text { ability, rigorous academic attitude, good } \\
\text { professional ethics, communication and team } \\
\text { cooperation abilities and be familiar with the } \\
\text { relevant requirements of practical teaching of } \\
\text { clinical pharmacy undergraduate students. } \\
\text { Ability to teach students how to carry } \\
\text { out therapeutic drug monitoring and } \\
\text { pharmacogenomic monitoring and use them } \\
\text { to guide individualized drug delivery'. }\end{array}$ \\
\hline
\end{tabular}


professional degree or related to ensure all the students will acquire the optimum knowledge, skills, abilities, behaviors and attitudes necessary to provide patientcentered care, manage medication use systems, promote health and wellness and describe the influence of population-based care on patient-centered care.

In addition, China 2018 accreditation standards did not mention how this program will be organized and staffed, what is the program vision and goals and even more what is the strategic and alternative plan if the program fails for any reason. It is just designed in a way that there is no any chance of system failure, this failure can be defined as technical, administrative or curricular failure.

\section{Subsection Two: Educational Program for the Doctor of Pharmacy Degree/Clinical Pharmacy Bachelor's Degree}

Although both programmes have immense similarity with each other, when compared China 2018 accreditation standards curriculum to ACPE 2015 accreditation standards curriculum, the foundational knowledge core is faced with three problems. The first problem is that, there is an enormous gap in compulsory courses that should be taught to students (such as ACPE 2015 accreditation standards curriculum clinical science courses section), to develop the student's comprehensive knowledge that required to be 'practice ready' and the ability to retain, recall, build upon this knowledge to be able to deliver quality patient care in a variety of entrylevel practice settings. The second problem is that the program is taught full in Chinese, so the graduates will face in the future huge problems and hindrances to practice outside the country or even contribute in international conferences or workshops since all the drugs names and clinical content is taught in Chinese.

\section{Subsection three and four: student and resources}

Meanwhile, China 2018 accreditation standards have successfully managed and developed strong guidance and teaching program for different health care facilities called practical teaching base. The practical teaching base program is defined as the medical institution that commences practical teaching work for clinical pharmacy students. The practical teaching base consists of pharmaceutical departments and clinical specialties of eligible medical institutions.

General requirements of the practical teaching bases in China:

(1) The practical teaching base should be conducted in grade three A or grade three B hospitals (hospitals in
China are classified into private and governmental hospitals and each hospitals category has their own specified grade)

(2) It should be equipped with teaching equipment, qualified classrooms and clinical skills simulation training centres to meet the needs of practical education.

(3) Library with a wide range of resources and professional books, computers, information retrieval systems and network platforms that meet the needs of practical education is needed.

(4) The ability to provide certain services such as dorms and food areas that meet the daily needs of students.

(5) Each clinical pharmacy practice base must have person in charge whose responsibility is to organize, coordinate, supervise and manage the practical teaching base.

(6) The hospital should have more than 3 years of experience in organizing practical teaching bases and standardized teaching file management methods.

(7) There should be a systematic clinical pharmacy professional practice teaching program, teaching outline, implementation plan and other teaching documents.

(8) There should be a dynamic management evaluation mechanism to evaluate the student's practical results and the instructor's teaching quality. Teaching work should be considered as an important indicator to assess discipline construction and tutors' performance.

(9) Practical teaching bases organizers should sign clinical pharmacy practice teaching agreements with relevant universities to implement the teaching program in health facilities and manage relevant education personnel.

(10) Relevant universities and practical teaching bases should establish coordination mechanisms, training standards, teaching process evaluation, medical safety education and innovate teaching methods.

So, it is factual that China accreditation standards has built a strong internship program for the students same to APPE program, but as mentioned above there is a vast gap in the accreditation standards foundational science knowledge and this could affect the training program in the health facilities. For example, the internship program includes pharmacogenomic monitoring, unless the students' study pharmacogenomic as a foundational course the preceptors will struggle in the teaching process and because the internship time is limited there will be a huge waste of time.

Other problems lie in the evaluation process of the preceptors, "How it will be conducted?" And "Is there will be a regular workshops, seminars and conferences for the preceptors and teaching staff to hold the consistency, teaching and development of the internship program or not?" 


\section{Table 6: Comparison of Assessment and Evaluation Elements Between ACPE 2015 and China 2018 Programs}

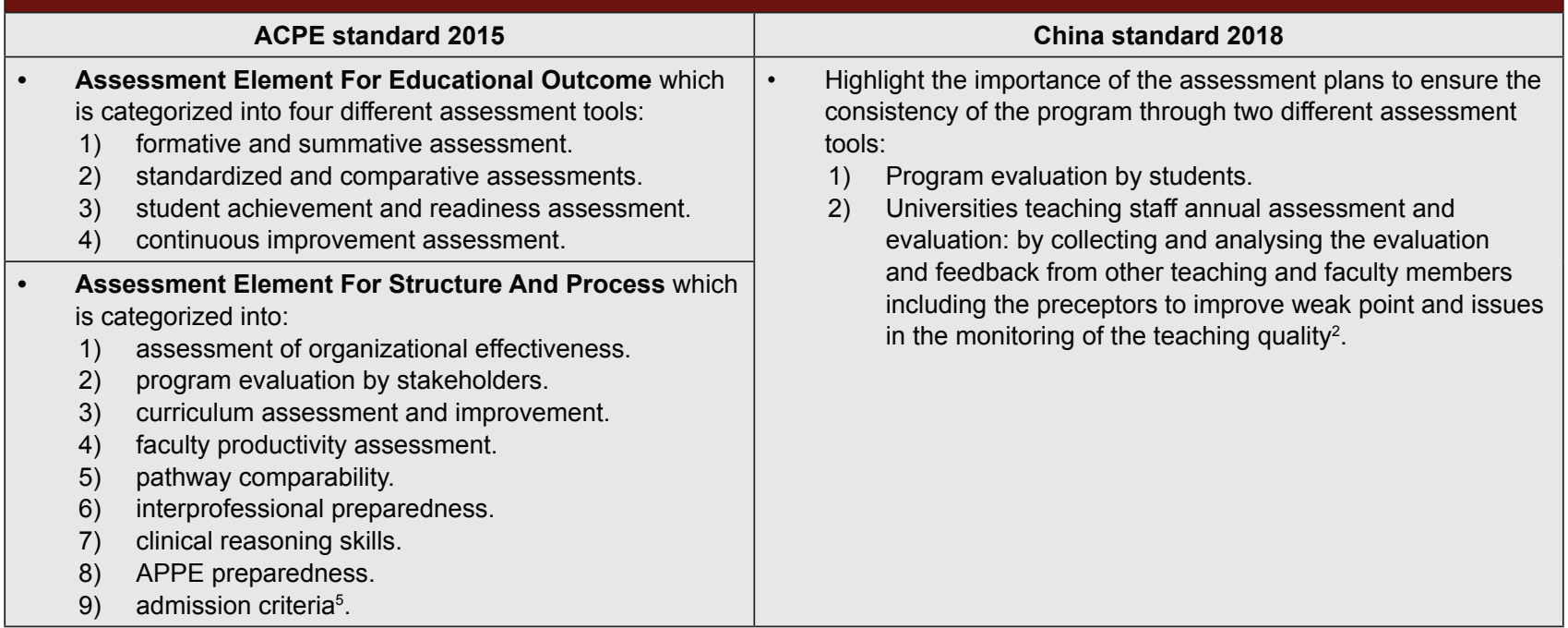

\section{Section Three: Assessment and Evaluation}

In the spirit of continued quality improvement and transparency, each college and school must report and evaluate to constituents the extent to which they meet their programmatic goals. Strategic planning, educational programs and other institutional initiatives are directed into constructive change to enhance programmatic goals. Different assessment and evaluation elements adopted by the ACPE 2015 accreditation standards and China 2018 accreditation standards are shown in Table 6.

Unfortunately, China curriculum does not state: 1) what are the admission criteria and policies to ensure the selection of a qualified and diverse student members. 2) what is the conduct assessment tool plan for the graduation internship program to define what level of competence in professional knowledge patient-based care and medication therapy management skills the graduates have to reach. 3) what is the alternative pathways to the degree completion such as online or distance learning programmes. And 4) what is the plan to assess and measure students achievements and defined levels of the professional capabilities.

\section{CONCLUSION}

To ensure the continuity, organized and successfully achievement of the China 2018 accreditation standards outcomes and goals, the program needs periodically assessment and evaluation from universities and colleges to enhance programmatic quality. This assessment must be implemented in each bend of clinical pharmacy program. Otherwise, the program will have a lot of failures and blunders, to overcome these problems, several things need to be considered:

1. To ensure the consistency of the program, several assessments tools need to be implemented:

(A) Back to the foundational knowledge section, students need annual assessment until graduation and the faculty members need to collect and summarize overall student achievement of relevant didactic, internship and graduation internship programs.

(B) Assessments of student achievement of problem-solving, critical thinking and student's ability to communicate professionally with patients.

(C) Each university or college needs to set up their goals, mission and future plans and annually assesses these goals through documents including description of the process how these strategic plans have been developed.

(D) Conduct self-assessment tool used by students to document their learning needs, achievements, plans and professional growth.

2. Responsibilities of the dean and other administrative leadership team members need to be clearly stated.

3. Policies and procedures related to the system failures and contingency planning need to be stated.

4. Description of the curricular and degree requirements by recording of required curricular content and tabular display of courses.

5. Designing curriculum committee members with position or affiliation within college or school. 
6. The curriculum needs to state policies and procedures regarding the admission process including selection of admitted students and course waiver policies.

\section{ACKNOWLEDGEMENT}

Authors express deep gratitude and appreciation to the Ministry of Education of People Republic of China (MOE) and China Teaching Committee for their time and effort to prepare a new national accreditation for teaching clinical pharmacy bachelor's degree. This work was Supported by the Teaching Reform Project of China Pharmaceutical University in 2019 (No.3050120030).

\section{CONFLICT OF INTEREST}

The authors declare no conflict of interest.

\section{ABBREVIATIONS}

MOE: China Ministry of Education of People's Republic of China; ACPE: Accreditation Council of Pharmacy Education.

\section{REFERENCES}

1. Jiang $\mathrm{JH}$, et al. Clinical pharmacy education in China. American Journal of Pharmaceutical Education. 2011;75(3):57c.

2. Teaching Committee of colleges and Universities, the Ministry of Education. The national Standard of the Teaching Quality of the Undergraduate Major in the General Institutions. Higher Education Press. 2018;708-15. 教育部高等学校教 学指导委员会。

3. Carter BL. Evolution of Clinical Pharmacy in the USA and Future Directions for Patient Care. Drugs and Aging. 2016;33(3):169-77.

4. Vlasses PH, Wadelin JW, Travlos DV. Accreditation Council for Pharmacy Education: Annual Report. American Journal of Pharmaceutical Education. 2012;76(8):45

5. ACPE accreditation council for pharmacy education. 2015.

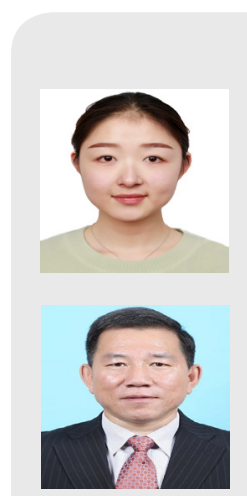

About Authors

Qi-Yue Zhang, School of Basic Medicine and Clinical Pharmacy, China Pharmaceutical University.

Dr. Chang-Qing Yang, Professor, Department of China Pharmacy, School of Basic Medicine and Clinical Pharmacy, China Pharmaceutical University, CHINA. He is actively involved in Researches of Clinical Pharmacy and Clinical Pharmacokinetics, Clinical Pharmacy Education, metabolic pathway of innovative drugs, etc, published more than 80 research papers in various national and international journals.

\section{SUMMARY}

Pharmaceutical education in China is now more oriented to solve problems and to provide the best patient care by building and developing of new national accreditation and standards by ministry of education of People's Republic of China (MOE). This accreditation will play an important role in clinical pharmacy education. In order to meet the requirements of this accreditation, this will be launch in the next fall semester and each university/college must implement the new united national accreditation.

Although China has made a considerable progression in developing the clinical pharmacy education, still there is lack of important goals, assessment tools and curriculum content to fulfil the students satisfy and complete gain of knowledge which in future could affect the students achievement to practice and team ready.

Dr. Zeinab Abdelrahman, Ph.D Clinical Pharmacy, School of Basic Medicine and Clinical Pharmacy, China Pharmaceutical University, Sudanese clinical pharmacist graduates from University of Khartoum, worked as Assistant Clinical Preceptor at different hospitals, volunteer teaching assistant at University of Khartoum, PhD specialty at clinical pharmacokinetics and drug metabolism in micro-organism.

Cite this article: Abdelrahman Z, Zhang QY, Yang CQ. Comparative Study Between China 2018 National Accreditation Standard for Teaching Quality of Clinical Pharmacy and ACPE 2015 Accreditation Standards and Guidelines. Indian $\mathrm{J}$ of Pharmaceutical Education and Research. 2019;53(4):629-37. 